\title{
Wetland Utilization and Environmental Implications on the North and Southern Slopes of Mount Cameroon
}

\author{
Fidelis Orock Tanyi ${ }^{1} \&$ Sunday Shende Kometa ${ }^{2}$ \\ ${ }^{1}$ Department of Geography, University of Buea, Cameroon \\ ${ }^{2}$ Department of Geography, HTTC, The University of Bamenda, Cameroon \\ Correspondence: Sunday Shende Kometa, Department of Geography, HTTC, The University of Bamenda, \\ Cameroon. E-mail: shendek@hotmail.com
}

Received: November 12, 2014 Accepted: April 21, 2015 Online Published: June 15, 2015

doi:10.5539/jas.v7n7p103

URL: http://dx.doi.org/10.5539/jas.v7n7p103

\begin{abstract}
The need for a more rigorous fight against environmental degradation in general and wetland extinction in particular is important if we have to eradicate poverty and hunger by the year 2035. Wetlands in the north eastern and southern slopes of the Mount Cameroon region are plagued by two categories of threats (stressors) which are of natural and anthropogenic origin. Since April 2009, most of the inland wetlands environs are suffering from a severe plague that is causing the death of Colocasia esculenta - the main food crop cultivated in the inland wetlands in the region. Using questionnaires, interviews, topographic and climatic maps and physico-chemical analysis the paper examines the spatial assessment of wetland exploitation, and also examines the cause of the wilting of the crop (Colocasia esculenta) cultivated in inland wetlands in the region. The ecological implication reveals that the annual decrease in the total input of rainfall is causing a gradual decline of wetlands in the region, particularly as this decrease is accompanied by a commensurate increase in the rate of evapotranspiration. Laboratory analysis revealed that Pythium myriotylum, a fungus-like micro organism is a contributing factor that is causing the wilting of Colocasia esculenta. Invasive plant species therefore pose a major threat to biodiversity and the high degree of wetland degradation relates to the absence of wetland sensitization programmes by the government, Municipal Councils, Traditional Councils, Chiefs, Quarter Heads and Non-Governmental Organisations.
\end{abstract}

Keywords: wetland, environmental implication, colocasia esculenta, Mount Cameroon

\section{Introduction}

As the first decade of the $21^{\text {st }}$ Century continues to unfold, it is incumbent on communities to set up succinct environmental policies and wetland action plans to meet the pace at which the current generation is embarking on technological changes. Driven by man's ingenuity, the present generation is doing everything to survive at the expense of the natural ecological systems, notably wetlands. The need for a more rigorous fight against environmental degradation in general and wetland extinction in particular is important if we have to eradicate poverty and hunger by 2035 . Besides, it equally lies on the need to reactivate the regenerative capacity or resilience of the entire biological resources of the earth for posterity, since the latter plays a key role in the sustenance of the human race. Wetlands are very important strategic ecosystems that have attracted human attention in recent years. They are strategic in the sense that they perform dual concomitant services to man and nature. These include addressing the poverty needs of humanity and at the same time conserving earth's resources and purifying the environment. Unfortunately, there is a progressive relegation of the latter functions, despite their importance.

The idea that wetland degradation is currently taking place in almost every part of the world is not a fallacy. In the face of astronomical population growth experienced in recent years (Waugh, 2002), the rate at which wetlands are degraded and transformed is alarming (Williams, 1991), particularly in regions where environmental policies and action plans are either absent, still at the conception phase or are moribund. This has placed humanity at an environmental crossroad, confronted by a daunting predicament to establish harmony between socio-economic development and wetland conservation (Cunningham et al., 2002).

Wetlands in the north eastern and southern slopes of the Mount Cameroon region are plagued by two categories 
of threats (stressors) which are of natural and anthropogenic origin. Past phases of volcanic eruptions have left an inordinate impact on the wetlands in the region, particularly as part of the study area falls within the active volcanic slope of Mount Cameroon. The presence of old lava flows in some parts of the coast is an indication of the fact that lava has modified the coastal wetlands over the past years by obliterating some coastal marshes, swamps and mangrove ecosystems that laid on their paths. Apart from the above, biological problems notably pest, diseases, and invasive species are ushering in a new dimension of threats on the existing wetlands in the region. Since April 2009, most of the inland wetlands environs are suffering from a severe plague that is causing the death of Colocasia esculenta - one of the main food crop cultivated in the vicinity of the inland wetlands in the region. The unknown plague is currently causing the wilting of this crop in all the wetlands from Limbe in the south west to Malende in the north east. The leaves of most of the infested crops depict some yellowish-brown spots and when a comet of Colocasia esculenta harvested from these wetlands is cut, it is observed that their colour changes from white to brown. Farmers who cultivate these crops have observed that as soon as the crops are harvested, they rot within two to three days. This shows that these wetlands have pathological problems. This paper attempts $t$ a spatial assessment of wetland exploitation in the area and brings out the cause of the wilting of Colocasia esculenta cultivated in these wetlands.

\section{The Study Area}

The North and Sputhern slopes of Mount Cameroon extends from latitudes $3^{\circ} 50^{\prime}$ to $4^{\circ} 25^{\prime}$ North of the equator and from longitudes $8^{\circ} 55^{\prime}$ to $9^{\circ} 35^{\prime} \mathrm{E}$ of the Greenwich Meridian. The region is characterized by intense precipitation for most of the year, even though its distribution is not uniform. Both equatorial and tropical climatic types exist. The mean annual precipitation varies from the south west to the north east as illustrated in Figure 1 and this follows the orientation of the Cameroon Volcanic Line. Despite the existence of this local variation, there is a high rainfall probability in the region. The topography is uneven as it is characterised by highlands and lowlands, with the former dominated by mountains and volcanic cones. Two mountains exist in the region: Mounts Cameroon and Etinde, with respective altitudes of 4,095 $\mathrm{m}$ and 1,713 $\mathrm{m}$ above sea level.

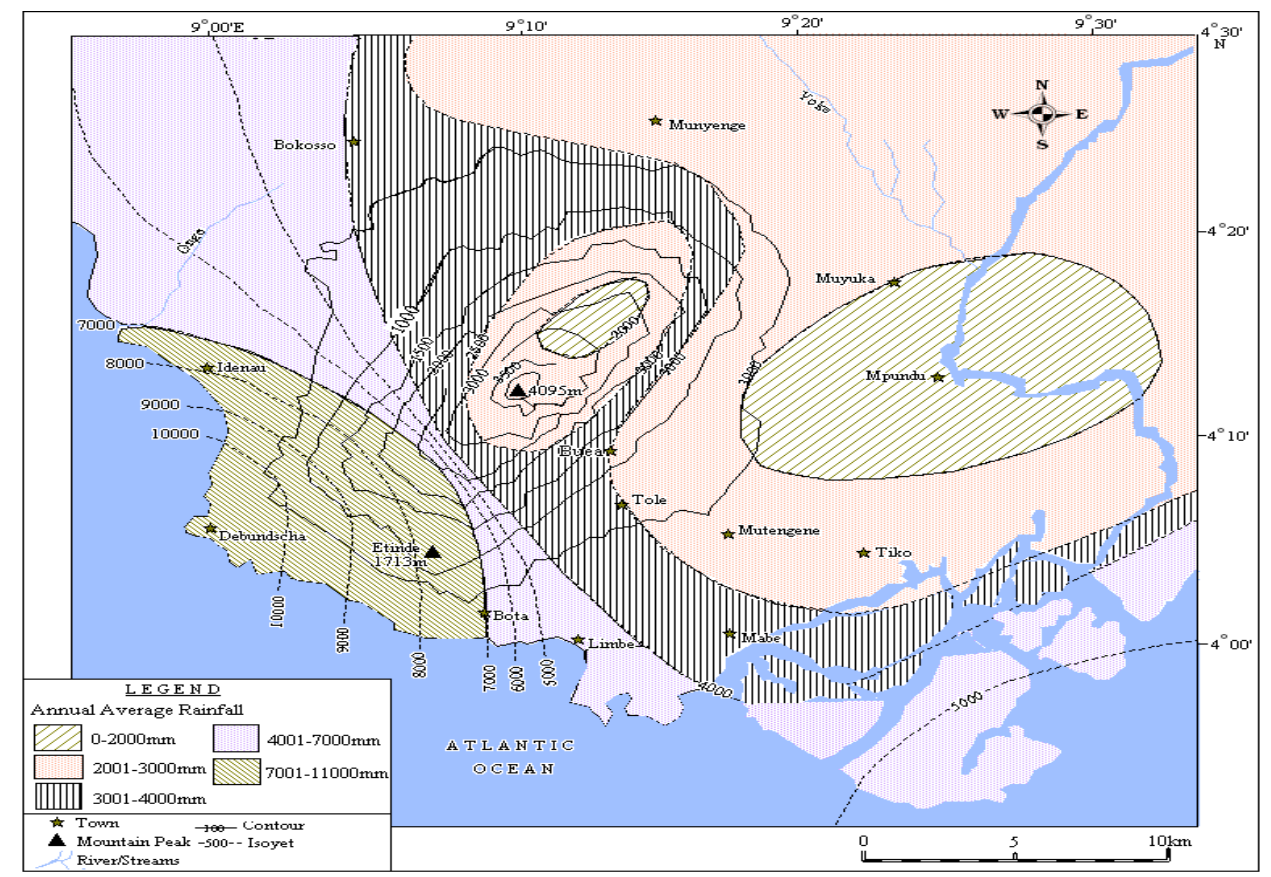

Figure 1. Spatial variation in mean annual rainfall in the north eastern and southern slopes of Mount Cameroon

The nature of the hydrogeology plays a very significant role in the location and spatial variation of wetlands in the region. Wetlands mostly occur in regions where the underlying geology is characterised by the presence of rocks with a high storage capacity. These geologic units have a significant influence on the hydrography of the region in the sense that areas with abundant presence of pyroclasts have fewer wetlands, since these rocks have high porosity and low storage capacity. Two types of aquifers exist in this region: perched and regional aquifers. As it lies above the regional water table, springs ooze from the former at different altitudes. 
Due to frequent volcanic eruptions, volcanic soils with a high concentration of calcium and magnesium cover a large part of the region. These soils are generally divided into two categories: young volcanic soils and old volcanic soils. Young volcanic soils are mostly reddish in colour, originating from the weathering of recent lava flows. Old volcanic soils are dark brown sandy clay soils, mostly developed in the lowlands. Besides the volcanic soils, there also exists sedimentary soils, the greatest concentration of which is in the Tiko Plain where they constitute the Tertiary-Quaternary sedimentary deposits. Also, the population has increased steadily from 157,032 inhabitants in 1976 to 432,427 inhabitants in 2010, giving a percentage increase of 175.4 within a span of 34 years. This indicates an annual growth rate of $4.1 \%$ between the observed periods and an increase in the population density from 76.2 to 209.7 persons per $\mathrm{km}^{2}$ within the same period. This must have greatly enhanced the pressure on resources in the region.

\section{Materials and Methods}

\subsection{Topographic and Field Data}

In order to map out the wetlands in the region, the topographic map of Buea-Douala of the Federal Republic of Cameroon, NB-32-IV-1b of June 1969, with the scale 1:50 000 was used. Maps of the Mount Cameroon region (in TIF image) were geo-referenced, and the different wetland types were digitized using the remote sensing software, ENVI and ArcGIS (Geographic Information System). After digitizing, the total areas covered by wetlands on the north eastern and southern slopes of Mount Cameroon were determined. The Global Positioning System-Magellan (Explorist 100) was used to locate some inland wetlands and the spatial extent of the mangroves. In order to illustrate the evolution of human activities over space and time in the region, satellite images of different periods were analysed. Images of two years were analysed namely, 1986 and 2000. The choice of limiting the satellite image interpretation to these two years was because of the absence of clear satellite images for other years and the presence of numerous cloud bands on the few available images taken from 2000 to 2008 .

Using a stratified random sampling method, two hundred questionnaires were administered to obtain information from the inhabitants in relation to wetland perception, status, ownership, importance/uses, impact of exploitation, sensitisation and management. A total of one hundred questionnaires were administered along the coast while one hundred were administered inland. From the number of questionnaires allocated for each locality, every fourth house was interviewed in the different regions to avoid bias and ensure uniformity. The data obtained was analysed using parametric (percentages) and non parametric methods-analysis of variance (ANOVA). The latter was used because it is a good statistical method which should be deployed in a situation where there are multiple means to be analysed from a given set of data.

\subsection{Climatic Data}

Climatic data were obtained from six weather stations that span across the entire region. Rainfall and temperature data were obtained from Debundscha in the south west, Likomba and Tiko in the south east and Meanja in the north east. Due to the existence of information gaps in the collection and recording of climatic data from the various stations, the means were collected at different intervals. Data obtained were used to assess the rate of spatio-temporal changes in mean annual rainfall and temperature as well as total rainfall amounts over well determined periods. Analysis was done using moving averages on yearly values. Regression coefficients were fitted to determine the gradient of each trend and then projections of the mean rainfall and temperature above 2010 were made, based on the nature of the trends. Since rainfall is the main source of input into the wetlands, the variation in total annual input with time was determined using bar graphs. On each graph, regression lines were also fitted to show the general trend and regression coefficients were added to determine the nature of the trend.

\subsection{Physio-Chemical Data}

Wetland sampling for physico-chemical properties and microbial quality were carried out in order to determine current wetland quality and its spatial variation. Twenty-five samples were randomly collected from twelve sample sites across the entire region, out of which six of the sites were coastal wetlands and six were inland wetlands. Thirteen of the samples were for the analysis of physico-chemical properties while twelve were for the analysis of microbial qualities. In one of the sample sites, an additional sample was collected for the analysis of trace metals. The samples were collected in the dry season. Using autoclaved and labelled containers, dual samples were collected at each sample site: one for the analysis of physico-chemical properties and the other for the analysis of microbial quality. To determine the cause of the wilting of Colocasia esculenta cultivated in the inland wetlands, two samples were randomly obtained from Mussaka and Ekona for microbial analysis. The two infested crops were taken from these sites because the plague is reported to have originated from these areas. The 
soil on the roots of the crops was equally collected for analysis of inherent physico-chemical properties so that ionic comparison could be made.

The analysis of physico-chemical properties was done using selective electrodes. The following physico-chemical properties were analysed from the wetland samples: sodium $\left(\mathrm{Na}^{+}\right)$, potassium $\left(\mathrm{K}^{+}\right)$, calcium $\left(\mathrm{Ca}^{2+}\right)$ and magnesium $\left(\mathrm{Mg}^{2+}\right)$ as cations, while anions were chloride $\left(\mathrm{Cl}^{-}\right)$, sulphate $\left(\mathrm{SO}_{4}{ }^{2-}\right)$, phosphate $\left(\mathrm{PO}_{4}{ }^{3-}\right)$, bicarbonate $\left(\mathrm{HCO}_{3}{ }^{-}\right)$and nitrate $\left(\mathrm{NO}_{3}{ }^{-}\right)$. Some heavy metals analysed were: barium $\left(\mathrm{Ba}^{2+}\right)$, silver $\left(\mathrm{Ag}^{+}\right)$, lead $\left(\mathrm{Pb}^{2+}\right)$, mercury $\left(\mathrm{Hg}^{2+}\right)$ and cadmium $\left(\mathrm{Cd}^{2+}\right)$. Both wetland samples and Colocasia esculenta samples were used to culture and to determine the growth of specific bacteria. With regards to the water samples for microbial analysis, Brain Heart (BH) Infusion Broth was used to inoculate the samples before incubating them at $37^{\circ} \mathrm{C}$ for 48 hours. The resultant growth was later sub-cultured on MacConkey Agar, Samonella Shigella Agar and Eosin Methylene Blue (EMB) Agar. MacConkey agar enhances differential growth while Samonella Shigella Agar and Eosin Methylene Blue (EMB) Agar enhance selective growth.

With regards to the Colocasia esculenta sample, a piece of it was cultured in Yeast-Mold Broth at room temperature for seventy two hours (three days). The purpose of culturing at room temperature was to facilitate growth within an environmental temperature. Since Potato Dextrose Agar (PDA) and Sboraud Dextrose Agar (SDA) were not available, the growth obtained was sub-cultured in Nutrient Agar for differential growth and in Brain Heart (BH) and Thioglocolate (TG) Broth media for selective growth. In order to make an assessment of the correlationship between settlement location and the concentration of Total Coliforms in the wetlands, the Spearman's rank correlation coefficient was used. The collected soil samples were first dried in an oven for forty eight hours, after which various extractions were made. $\mathrm{PH}\left(-\log \mathrm{H}^{+}\right)$was measured using the Thermo-russel $\mathrm{pH}$ meter. The meter was calibrated using buffer solutions of $\mathrm{pH} 4$ and 7. In this process, $10 \mathrm{~g}$ of $2 \mathrm{~mm}$ air dry soil samples were weighed into beakers. $25 \mathrm{ml}$ of 1 normal potassium chloride was added to the samples and $25 \mathrm{ml}$ of distilled water was equally added to the other set of beakers with $10 \mathrm{~g}$ of the sample. The soil/solution mixture was stirred using a stirring rod and left overnight. The $\mathrm{pH}$ was read the next day. To determine the particle sizes of the soil samples, $15 \mathrm{ml}$ of $2 \mathrm{~mm}$ air-dry soil was weighed in a $500 \mathrm{ml}$ beaker and subjected to the following treatment: first, organic matter was destroyed using hydrogen peroxide. Secondly, chemical dispersion of the samples was done using sodium hexametaphosphate and sodium carbonate, followed by a mechanical dispersion using an End-to-End Shaker. Later, Pipetting was done using the Reuben's pipette in consonance with Stokes Law. The soil fractions were pipetted at a depth of $10 \mathrm{~cm}$ in a sedimentation flask after 4 minutes 16 seconds at a temperature of $28^{\circ} \mathrm{C}$.

Total nitrogen was extracted using the Kjeldahl method. For this to be realised, the soil samples were digested at $370{ }^{\circ} \mathrm{C}$ on a Tacator Block Digestor with concentrated sulphuric acid, in the presence of a sodium sulphate/selenium catalyst (Kjeldahl method). For extraction, $0.5 \mathrm{~g}$ of $0.5 \mathrm{~mm}$ air dry soil sample was weighed into clean Tecator digestion tubes. Five (5) millilitres (ml) of concentrated $\mathrm{H}_{2} \mathrm{SO}_{4}$ was added into it in the presence of the catalyst and then digested using the Tacator block for 2 hours 30 minutes at $370{ }^{\circ} \mathrm{C}$. The extract was allowed to cool before diluting to $100 \mathrm{ml}$. Organic carbon was extracted using the Walkley black method, determined using colorimetry and read using the spectrophotometer at $\lambda=650 \mathrm{~nm}$. In order to determine the available phosphorus (p), solutions of $0.1 \mathrm{~N} \mathrm{HCL}$ and $0.03 \mathrm{~N} \mathrm{NH}_{4} \mathrm{~F}$ were used to extract the available phosphorus from the soil. Phosphorus was then determined colorimetrically using the ammonium molybdate blue coloration method. Magnesium $\left(\mathrm{Mg}^{2+}\right)$ in the soil was determined by colorimetry and read in a spectrophotometer. Extraction was done using $1 \mathrm{~N}$ ammonium acetate $\left(\mathrm{NH}_{4} \mathrm{OAc} \mathrm{pH} 7\right)$, alongside other bases $\left(\mathrm{Ca}^{2+}, \mathrm{K}^{+}, \mathrm{Na}^{+}\right)$and determined colorimetrically on a spectrophotometer (colorimeter). Coloration was done using the "Titan Yellow" method in which, $1 \mathrm{ml}$ of the soil extract was pipetted into clean test tubes alongside the standards. $4 \mathrm{ml}$ of the calcium chloride $\left(\mathrm{CaCl}_{2}\right)$ solution and $10 \mathrm{ml}$ of Titan Yellow mixtures were successively added. A comparative analysis of wetland quality between coastal and inland wetlands was then made through the use of scatter graphs.

\section{Results}

\subsection{Wetland Utilisation and Impact on the Environment}

Wetlands cover a total surface area of $201.32 \mathrm{~km}^{2}$, being $9.76 \%$ of Fako Division. This value is sub-divided as shown on Table 1. 
Table 1. Total surface area covered by wetlands in the north eastern and southern slopes of Mount Cameroon

\begin{tabular}{lll}
\hline Nature of wetland & Length (metres) & Area covered $\left.\mathbf{( k m}^{\mathbf{2}}\right)$ \\
\hline Permanent wetland: Mangroves and swamps & $197,611,010$ & 197.611 \\
Permanent streams and rivers & $1,059,544$ & 1.059 \\
Permanent marshes & 15,250 & 0.015 \\
Seasonal streams & $2,375,136$ & 2.375 \\
Seasonal marshes & 152,314 & 0.152 \\
Flood plains & 13,800 & 0.014 \\
Lakes (Keta and Nachtigal) & 83,179 & 0.083 \\
Man-made ponds & 8,875 & 0.009 \\
Total & $\mathbf{2 0 1 , 3 1 9 , 1 0 8}$ & $\mathbf{2 0 1 . 3 2}$ \\
\hline Total surface area of Fako Division & & 2060 \\
Percentage of surface area covered by wetlands in the Division & & $\mathbf{9 . 7 6}$ \\
\hline
\end{tabular}

Source: Field survey and morphometric analysis (2010).

Based on the Ramsar classification system, thirteen different categories of wetland types have been established in this region. Five categories of coastal/marine wetland types exist. These include categories A, E, D, F and I. With the exception of the category D wetland type (rocky marine shores), four of them are considered to be dominant in the region. They include:

- A (Shallow marine water below six metres);

- E (Beaches);

- F (Estuaries) and.

- I (Mangroves and swamps).

With respect to inland wetlands, both natural and man-made types exist. Eight categories have been identified. These include categories M, O, Ts, Y, Tp, 1, 2, and 8. Of these, four are considered to be dominant. They include:

- M (Rivers and streams);

- Ts (Seasonal flood plains, ponds and topographic water traps or depressions);

- Y (Springs) and,

- $\mathrm{Tp}$ (Permanent marshes/ponds).

In categories $\mathrm{M}$ and $\mathrm{Tp}$ wetland types, four endemic fresh water fish species have been identified. These include: Aphyosemion splendopleure, Aphyosemion poliaki, Aphyosemion volcanum and Heterotocus niloticus.

Over the past three decades, there has been a gradual decrease in the total amount of rainfall that annually replenishes the wetlands in the region. The rate of decrease is not uniform as regions such as Debundscha and Idenau are experiencing a slower rate of decrease (due to orographic effect imposed by Mount Etinde and the southwestern flank of Mount Cameroon) unlike at Likomba, Tole and Meanja in the south east. One would expect that in a typically humid tropical milieu like this one, increasing atmospheric temperatures associated with global warming may lead to more intensive convective uplifts accompanied by frequent convectional rainfall. But regression analysis shows a clear contrast to this presumption as annual rainfall totals are instead decreasing. The ecological implication is that the annual decrease in the total input of rainfall is causing a gradual decline of wetlands in the region, particularly as this decrease is accompanied by a commensurate increase in the rate of evapotranspiration. Since species inhabiting mountain environments are particularly sensitive to environmental changes (Lambi \& Ndenecho, 2010), the wetland ecosystem is gradually grinding towards its climatic threshold, resulting from climate change scenarios.

Of the 500 questionnaires administered, $68 \%$ of the population perceived wetlands as common property resources to be exploited by every individual. $66.8 \%$ of them perceived the mangroves as a depleting resource when overexploited. Thus, there is a consideration degree of awareness about the vulnerability of the mangroves. In this light, $68 \%$ of the respondents expressed the need for people to abstain from the buying and selling of wetlands, while $67 \%$ are of the opinion that wetlands should be conserved due to the important services rendered 
to the community. With regards to wetland status, only $49.8 \%$ of the inhabitants know that wetlands are owned by the government. This shows that more than half of the population in the region is ignorant of the law defining wetland ownership in the country. Also, it is generally seen that traditional and Municipal Councils do not own wetlands in the region as $100 \%$ of the respondents attested to this. Furthermore, 92\% of the respondents acknowledged that there is a current process of wetland commodification as more people are engaging in the buying, selling and transformation of wetlands into multiple uses. It is possibly on this basis that $63.2 \%$ of them expressed the need for the maintenance of their indigenous property right on the wetlands so as to consolidate their position, particularly as beaches are attracting a lot of attention in the region.

With regards to the impact of wetlands on the inhabitants, there is a general awareness that the over-exploitation of wetlands is creating adverse effects on the livelihoods of the inhabitants as attested by $82.6 \%$ of them. Also, $66.6 \%$ of the inhabitants are suffering from the Colocasia esculenta crisis. The rate of wetland pollution is very severe and up to $97.8 \%$ of the inhabitants attested to this observation, while $94.4 \%$ accepted that as wetland sizes are decreasing, the frequency of floods is increasing; especially as many people have constructed their houses on reclaimed wetlands. Of the 500 questionnaires administered, only $2 \%$ of the people noted that government officials often carry out wetland sensitisation programmes in the region, implying that $98 \%$ of the respondents strongly disagreed to this. Similarly, $99.4 \%$ of the respondents observed that council workers and counsellors do not carry out wetland sensitisation campaigns, while $97 \%$ noted that Chiefs and Quarter Heads do not also carry out wetland sensitisation programmes. Only $3 \%$ of the respondents observed that some Non-Governmental Organisations do carry out periodic sensitisation programmes when they visit the mangroves in the Tiko estuary during ecotourism. When combined, all of the respondents (100\%) did not agree that periodic sensitisation programmes are jointly carried out by the above stakeholders.

\subsection{Physico-Chemical Analysis}

From Table 2, it can be observed that the most dominant element is chloride. Very high concentrations above the $250 \mathrm{mg} / \mathrm{l}$ maximum permissible limit for Cameroon occurs in site 040 (Modeka creek) with a concentration of $2087.56 \mathrm{mg} / \mathrm{l}$ and in site 160 (Idenau stream) with a concentration of $2717.78 \mathrm{mg} / \mathrm{l}$. The highest concentration of chloride occurs in Idenau. The origin of the chloride is from the Atlantic Ocean. Idenau has the highest concentration probably because the locality is quite close to the ocean which favours the possibility of saline intrusion.

Table 2. Analytical results of physico-chemical properties of coastal wetland water samples

\begin{tabular}{lllllllll}
\hline \multirow{2}{*}{ Sample Code } & \multicolumn{8}{c}{ Parameters $\mathbf{( m g} / \mathbf{L})$} \\
\cline { 2 - 9 } & $\mathbf{N a}^{+}$ & $\mathbf{K}^{+}$ & $\mathbf{C a}^{2+}$ & $\mathbf{M g}^{2+}$ & $\mathbf{H C O}_{3}{ }^{-}$ & $\mathbf{C l}^{-}$ & $\mathbf{S O}_{4}{ }^{2-}$ & $\mathbf{N O}^{-}$ \\
\hline 040 & 701.50 & 48.50 & 80.23 & 216.55 & 110.10 & 2087.56 & 425.86 & 27.20 \\
060 & 14.00 & 2.90 & 40.12 & 36.50 & 08.00 & 39.33 & 43.49 & 0.60 \\
080 & 04.50 & 1.60 & 04.01 & 19.47 & 06.00 & 19.64 & 8.55 & 1.00 \\
100 & 108.30 & 1.60 & 24.07 & 36.50 & 48.05 & 118.11 & 33.51 & 5.80 \\
$140 \mathrm{~A}$ & 566.30 & 4.20 & 12.03 & 14.60 & 05.01 & 39.33 & 20.01 & 1.90 \\
160 & 596.40 & 60.00 & 84.24 & 279.81 & 80.06 & 2717.78 & 676.89 & 29.80 \\
\hline
\end{tabular}

Source: Field survey and laboratory analysis of samples (2010).

Table 3. Analytical results of sampling of coastal wetland for heavy metals

\begin{tabular}{llllll}
\hline \multirow{2}{*}{ Sample code } & Sample site & \multicolumn{4}{c}{ Parameters $(\mathbf{m g} / \mathbf{L})$} \\
\cline { 3 - 5 } & & Barium $\left(\mathbf{B a}^{2+}\right)$ & Silver $\left(\mathbf{A g}^{+}\right)$ & $\mathbf{L e a d}\left(\mathbf{P b}^{2+}\right)$ & $\mathbf{C a d m i u m}\left(\mathbf{C d}^{2+}\right)$ \\
\hline 140B & Behind SONARA Club-Limbe & 22.30 & 0.10 & 0.70 & 0.60 \\
\hline
\end{tabular}

Source: Field Survey and laboratory analysis of samples (2010).

The low lying nature of the region also enables the easy inflow of saline water into the adjacent wetlands. Similarly, high concentration of sodium above the $175 \mathrm{mg} / \mathrm{l}$ maximum limit for Cameroon and the $200 \mathrm{mg} / \mathrm{l}$ established by the World Health Organisation (WHO) occurs in site 040 (Modeka creek) with a concentration of 
$701.50 \mathrm{mg} / \mathrm{l}$, site $140 \mathrm{~A}$ (behind SONARA Club) with a concentration of $566.30 \mathrm{mg} / \mathrm{l}$ and in site 160 (Idenau stream) with a concentration of $596.40 \mathrm{mg} / \mathrm{l}$. These values indicate a high rate of pollution in these sites. On the other hand, calcium and bicarbonate concentrations in the various coastal samples are within acceptable limits as values fall below $100 \mathrm{mg} / 1$ and $305 \mathrm{mg} / 1$ respectively, according to Cameroon standards. With regards to magnesium, the maximum permissible limit for Cameroon is $30 \mathrm{mg} / \mathrm{L}$ but three sites have higher concentrations, namely, site 040 (Modeka creek) with $216.55 \mathrm{mg} / \mathrm{l}$, site 060 (behind the Tiko Rubber Factory) with a concentration of $36.50 \mathrm{mg} / \mathrm{l}$ and Site 100 (Down Beach-Limbe) with a concentration of $36.50 \mathrm{mg} / \mathrm{l}$. The possible source of the high concentration of magnesium in the above sites is from the weathering of ferromagnesian rocks in the region (pyroxene) and from decayed organic wastes. With regards to heavy metals, as compared to the WHO maximum permissible standard for potability, Table 3 shows that traces exist in the wetland behind SONARA Club-Limbe. These metals could have come from outside sources, possibly from some engineering works.

Unlike in the coastal wetlands, there was a lower concentration of minerals in the inland wetlands. As depicted in Table 4, lower amounts of bases exist. Sodium ranged from $6.0-46.60 \mathrm{mg} / \mathrm{l}$. with a mean of $27 \mathrm{mg} / \mathrm{l}$ while potassium ranges from $1.50-5.70 \mathrm{mg} / 1$, with a mean concentration of $3.70 \mathrm{mg} / \mathrm{l}$. Calcium and magnesium on the other hand range from 4.01-20.06 mg/L and 9.73-29.20 mg/l respectively, with corresponding means of 16.3 and $24.3 \mathrm{mg} / \mathrm{L}$. With regards to the anions, there was a higher concentration of chloride as compared to other cations as it ranged from 39.33 to $59.03 \mathrm{mg} / \mathrm{l}$, with a mean of $49.2 \mathrm{mg} / \mathrm{l}$. These values are however lower than the maximum permissible standard for Cameroon and that stipulated by the World Health Organisation. Bicarbonate and sulphate concentrations are also low as they range from $6.0-52.05 \mathrm{mg} / \mathrm{l}$ and $6.81-40.82 \mathrm{mg} / \mathrm{l}$ respectively, with corresponding means of 24.20 and $22.40 \mathrm{mg} / \mathrm{l}$. Nitrate concentration is not significant as values ranged from $0.70-1.80 \mathrm{mg} / \mathrm{l}$, with an arithmetic mean of $1.15 \mathrm{mg} / \mathrm{l}$. The above values demonstrate that chloride and sodium are the dominant elements in the inland wetland water samples, while nitrate is the element with the lowest concentration. The results also show that phosphate concentrations were zero.

Table 4. Physico-chemical properties of inland wetland water samples

\begin{tabular}{lllllllll}
\hline \multirow{2}{*}{ Sample code } & \multicolumn{7}{c}{ Parameters $\mathbf{( m g / L )}$} \\
\cline { 2 - 9 } & $\mathbf{N a}^{+}$ & $\mathbf{K}^{+}$ & $\mathbf{C a}^{2+}$ & $\mathbf{M g}^{2+}$ & $\mathbf{H C O}_{3}{ }^{-}$ & $\mathbf{C l}^{-}$ & $\mathbf{S O}_{4}{ }^{2-}$ & $\mathbf{N O}_{3}{ }^{-}$ \\
\hline 180 & 12.50 & 1.50 & 12.03 & 29.20 & 52.05 & 59.03 & 6.81 & 1.20 \\
220 & 46.60 & 2.90 & 20.06 & 29.20 & 35.03 & 39.33 & 18.80 & 0.70 \\
240 & 32.50 & 4.40 & 20.06 & 21.90 & 32.02 & 59.03 & 20.10 & 0.70 \\
260 & 18.40 & 5.20 & 20.06 & 29.20 & 10.01 & 39.33 & 40.82 & 1.80 \\
280 & 06.00 & 2.50 & 04.01 & 9.73 & 09.98 & 39.33 & 14.31 & 1.00 \\
340 & 45.50 & 5.70 & 20.06 & 26.76 & 06.00 & 59.03 & 31.25 & 1.50 \\
\hline
\end{tabular}

Source: Field Survey and laboratory analysis of samples (2010).

The scatter graphs (Figures 2, 3, 4, and 5) show that in the coastal wetlands, a stronger correlationship exists between sodium and chloride, sodium and potassium, potassium and calcium, magnesium and chloride, magnesium and bicarbonate, calcium and bicarbonate and potassium and bicarbonate, than in the inland wetlands. The stronger correlationship is portrayed by greater $\mathrm{R}^{2}$ values in the coastal wetlands which range from 0.5356-0.9959 unlike in the inland wetlands where the highest $R^{2}$ value is 0.4428 . 


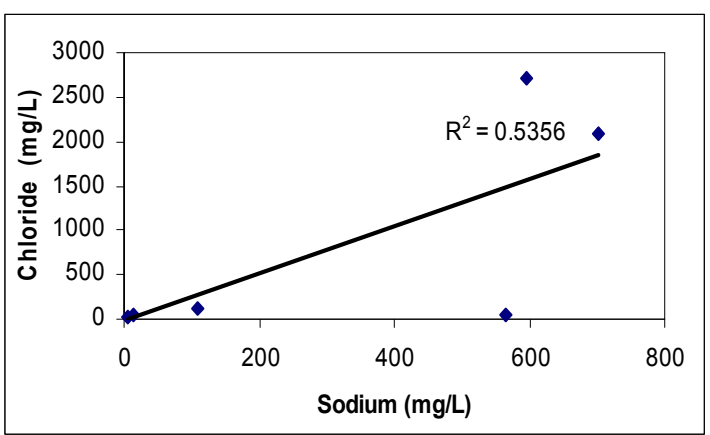

Coastal wetlands

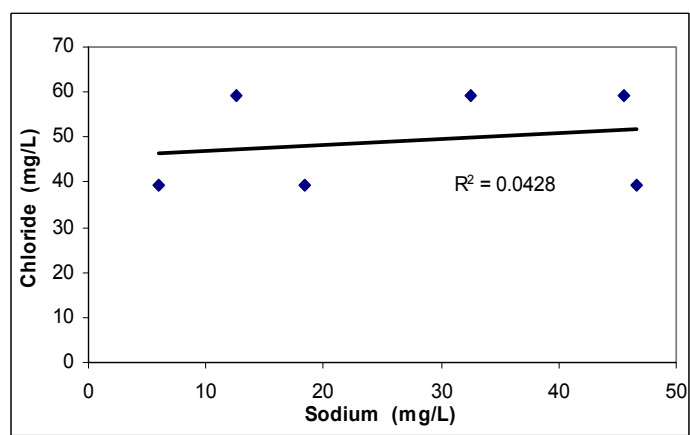

Inland wetlands

Figure 2. Scatter graphs showing a stronger correlationship between sodium and chloride in coastal wetlands than in inland wetlands

Source: Field survey (2010).

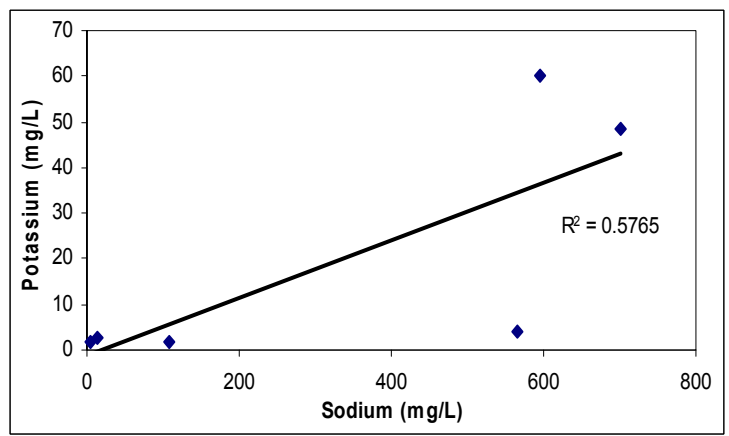

Coastal wetlands

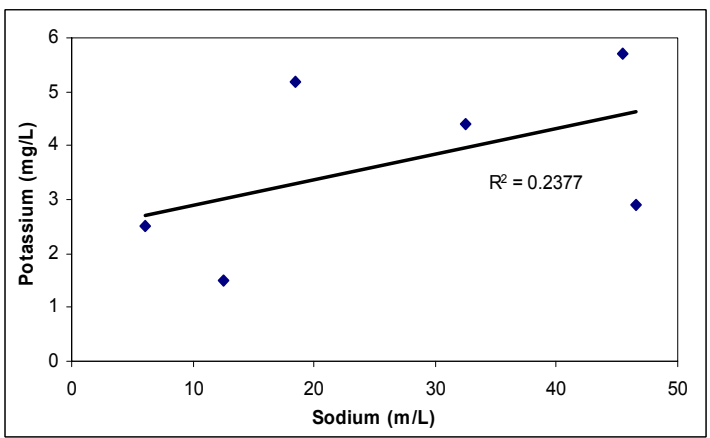

Inland wetlands

Figure 3. Scatter graphs showing a stronger correlationship between sodium and potassium in coastal wetlands than in inland wetlands

Source: Field survey (2010).

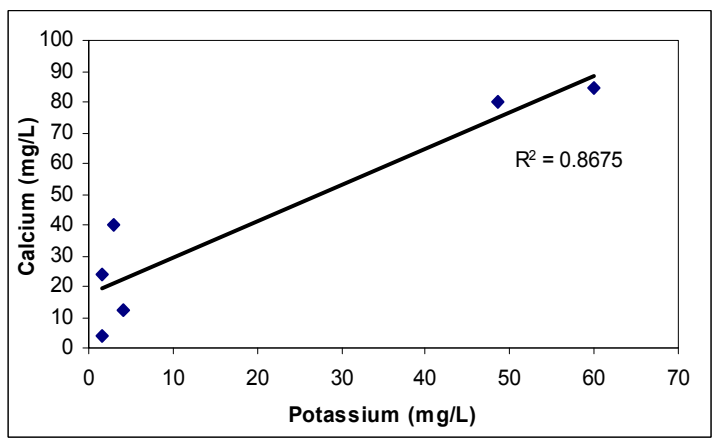

Coastal wetlands

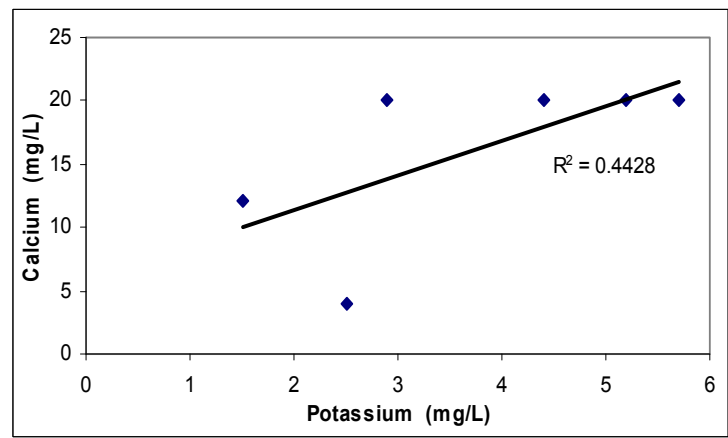

Inland wetlands

Figure 4. Scatter graphs showing a strong correlation between potassium and calcium in coastal wetlands than in inland wetlands

Source: Field survey (2010). 


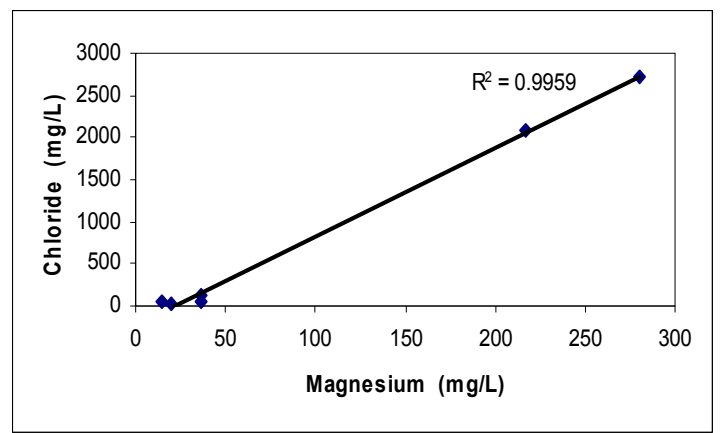

Coastal wetlands

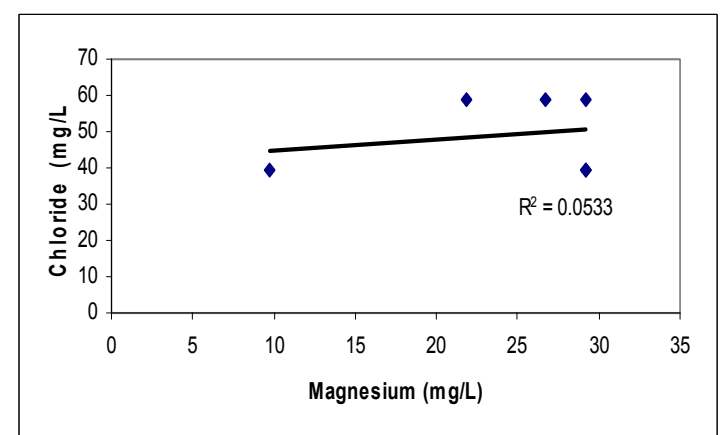

Inland wetlands

Figure 5. Scatter graphs showing a stronger correlationship between magnesium and chloride in coastal wetlands and a benign relationship between the two same elements in the inland wetlands

Source: Field survey (2010).

\section{Discussion}

Coastal wetlands appear to be more polluted than inland wetlands in the sense that they have all the five different types of microbes with higher levels of concentration. In terms of the standards prescribed by the Government of Cameroon and the WHO, their presence in the wetlands indicates high levels of pollution. This situation is similar to that of inland wetlands. Based on these values, it is evident that the wetlands on the north eastern slopes of the study area are highly polluted and this poses a health risk to the inhabitants in the region.

Laboratory analysis revealed that Pythium myriotylum, a fungus-like micro organism (Table 5) is a contributing factor that is causing the wilting of Colocasia esculenta cultivated in the wetlands in the region. This pathogen that has both terrestrial and aquatic adaptation strategies has left an immeasurable effect on the Colocasia esculenta crop in the region. By affecting the leaves, roots and comets of the crop, its photosynthetic ability is reduced, thus, reducing the ability for the crop to grow. The corollary of this is that the crop is forced to wilt. In the water samples collected for microbial analysis, Pythium myriotylum was not detected in any of them. This indicates that water is not a convenient habitat for the micro organism. It thrives and proliferates in food media like Colocasia esculenta and soils where abundant nutrients exist. Water rather serves as a transportation medium for the micro organism.

Table 5. Results of Colocasia esculenta samples

\begin{tabular}{lllll}
\hline Sample Code & Sample site & Nature of Sample & Nature of analysis & Type of organism detected \\
\hline 240 & Mussaka stream & Infested Colocasia esculenta comet & Culture and sub-culture & Pythium myriotylum \\
260 & Old Koke Stream-Ekona & Infested Colocasia esculenta comet & Culture and sub-culture & Pythium myriotylum \\
\hline
\end{tabular}

Source: Field Survey and Laboratory analysis of samples (2010).

Invasive plant species therefore pose a major threat to biodiversity in a given region. Unlike in the Lake Chad basin where two main invasive species, namely, Typa grass and Water hyacinth are causing biological threats in the region (as observed in the 2008 Strategic Action Programme for the Lake Chad Basin), five invasive species were identified in the region. These are Acrosticum, Bambusa vulgaris, Phoenix reclinata, Pandanus candelabrum and Nipa palms. They possibly originate from different regions, transported and deposited by the ocean. The existence of these invasive species in the coastal wetlands is a potential threat to the mangrove ecosystem, due to their colonising attribute. The invasive plant species identified in this study are different from those observed in the Everglades Region of the United States essentially dominated by Water Hyacinth, Climbing Fern, Malaleuca tree, saw grass and Brazilian pepper (Harris et al., 2004). This possibly relates to the variation in local factors such as their origin and rainfall intensity.

Different human activities are the principal sources of wetland degradation in the region. The relatively high presence of chemical properties in the coastal wetland samples indicates a high degree of pollution from industries, agriculture, domestic and commercial activities carried out both on the coast and inland. Elevated 
levels of pollution here confirm findings from earlier studies in the region (Ekane et al., 2001), Oben et al. (2001). The result is also similar to the situation in Ghana where the Oti River is experiencing increasing concentration of physico-chemical properties, with sulphate concentration for instance ranging from 0-200 mg/L (Abdul-Razak et al., 2009). Also, there were existing traces of heavy metals (Barium $22.30 \mathrm{mg} / \mathrm{L}$ ), in the wetlands

Most of the inhabitants are adversely affected by the degradation of wetlands in the region either directly or indirectly because they rely on most of the wetland services for their sustenance. The opinion noted by $82.6 \%$ of the population is that degrading wetlands are causing an adverse and very significant impact on their livelihood. When an ecological system is subjected to a prolonged stressor that may surpass its resilience, it ultimately becomes extinct. The path to extinction is as follows:

Threatened $\longrightarrow$ Vulnerability $\longrightarrow$ Endangered $\longrightarrow$ Critically endangered $\longrightarrow$ Extinction

Based on the results obtained, it appears that the wetland types identified are currently in a critical situation that needs an immediate remedial action.

\section{Conclusion}

To a large extent, the high degree of wetland degradation relates to the absence of wetland sensitization programmes by the government, Municipal Councils, Traditional Councils, Chiefs, Quarter Heads and Non-Governmental Organisations. Given that only $2 \%$ of the inhabitants acknowledge that they are being sensitized by the government, and 3\% by a few Non Governmental Organisations, it means that between 97 and $98 \%$ of the inhabitants have never been sensitized by any of the above stakeholders. This possibly explains why the wetlands are still looked upon as common property resources and this is the driving force behind their unsustainable exploitation. Likewise, none of the inhabitants is a member of any wetland management committee. Therefore, there is the absence of any participatory wetland management which calls for the development of an integrated wetland management system for the region, involving the active participation of all the stakeholders. The Government of Cameroon should harmonise legislative and institutional weaknesses while conserving the wetlands and at the same time improving the welfare of the inhabitants in the wetland-dependent communities.

\section{References}

Abdul-Razak, A., Aseidu, A. B., Entsua-Mensah, R. E. M., \& De Graft-Johnson, A. A. (2009). Assessment of the Water Quality of Oti River in Ghana. West African Journal of Applied Ecology, 15, 45-56.

Adger, W. N., \& Luttrell, C. (2000). The Value of Wetlands: Landscape and Institutional Perspectives. Property Rights and the Utilisation of Wetlands. Ecological Economics, 35, $75-89$. http://dx.doi.org/10.1016/S0921-8009(00)00169-5

Ayuk, E. O. (2005). Floral Phenology, Natural and Artificial Regeneration of Mangrove Communities at the Mudeka Creek, Cameroon (M.Sc thesis, pp. 34-50). University of Buea.

Beazley, M. (1993). Wetlands in Danger. A Mitchell Beazley World Atlas (p. 12). Published in association with IUCN-The World Conservation Union. Reed International Books Limited.

Bergkamp, G., \& Orlando, B. (1999). Wetlands and climate: Exploring collaboration between the convention on Wetlands (Ramsar, Iran, 1971) and the UN Framework convention on climate change (pp. 1-35). IUCN.

Central Bureau for Census and Population Studies. (2010). National Population Census Results.

Convention on Biodiversity. (2006). Ramsar Text of Presentation on wetlands and livelihoods. In N. Davidson (Ed.), Ramsar Convention on Wetlands, CBD COP 8 side event. Curitiba, Brazil.

Current Status and Conservation of Mangroves in Africa: An Overview. The World Resource Monitoring (WRM) Bulletin 33/TI. Retrieved from http://www.wrm.org.uy/bulletin/133/T1

Deo, P. C., Tyagi, A. P., Taylor, M., Becker, D. K., \& Harding, R. M. (2009). Improving taro (Colocasia esculenta var. esculenta) production using biotechnological approaches. South Pacific Journal of Natural Sciences, 27, 6-13. http://dx.doi.org/10.1071/SP09002

Donnellan, C. (2001). Population Growth (Vol. 20, pp. 6-21). Independence Educational Publishers, Burlington Press, Cambridge.

Ebot Tambe, M. A. T. (2002). Some Geomorphological Aspects of the Eastern slopes of Mount Cameroon (M.Sc. thesis, pp. 119-143). University of Buea. 
Ekane, N. D., \& Oben, P. M. (2001). Biochemical Indicators of Marine Pollution in the Douala Lagoon and Limbe Estuary. In C. M. Lambi (Ed.), Environmental Issues: Problems and Prospects (pp. 119-132). Unique Printers, Bamenda.

Endeley, R. E., Ayonghe, S. N., \& Tchuenteu, F. (2001). A Preliminary Hydrogeochemical and Baseline Study of Water Sources around Mount Cameroon. Journal of the Cameroon Academy of Sciences, 1(3), 127-185.

FAO Corporate Document Repository. (1998). Ramsar Wetland Classifications: Implications on the Conservation and Wise Use of Wetlands in Africa. Wetland Characterisation for Sustainable Agricultural Development.

Fraser, P. J., Hall, J. B., \& Healey, J. R. (1998). Climate of the Mount Cameroon Region. Long and Medium Rainfall, Temperature and Sunshine Data (p. 4). Mount Cameroon Darwin Initiative Project, University of Wales, Bangor, United kingdom.

Frazier, S. (1996). An overview of the world's Ramsar sites (Vol. 29, p. 58). Wetlands International Publication.

Ghogomu, R. (2001). The Geology of Cameroon: An Update. In C. M. Lambi \& Eze (Eds.), Readings in Geography (pp. 74-75). Unique Printers, Bamenda.

Gilman, E. L., Eric L., Ellison, J., Duke, N. C., \& Field, C. (2007). Threats to Mangroves from Climate Change and Adaptation Options (pp. 1-14). Aquat. Bot. (In Press).

Hardin, J. G. (1968). The Tragedy of the Commons. Science, 162, 1243. http://dx.doi.org/10.1126/science.162.3859.1243

Kabii, T. (2005). Ramsar wetland classification: Implications on the Conservation and Wise Use of wetlands in Africa (pp. 1-7). Africa Ramsar Convention Bureau.

Kometa, S. S. (2001). Human Adaptation in the Tiko Estuarine Environment. In C. M. Lambi (Ed.), Environmental Issues: Problems and Prospects (pp. 147-157). Unique Printers, Bamenda.

Kometa, S. S. (2005). The Impact of Natural and Man-Induced Hazards in Fako Division (S. W. Province) of Cameroon (Ph.D thesis, pp. 1-2). University of Buea.

Kometa, S. S. (2009). Wetland Exploitation and its Environmental Impact: The Case of the Bafoussam-Bamenda Axis of the Western Highlands of Cameroon. Conflict Prevention, Management and Resolution (pp. 25-37). Proceedings of the Postgraduate Seminar organized by the Faculty of Social and Management Sciences of the University of Buea, Cameroon. II PGS. Buea, 28th of January 2009.

Kometa, S. S., \& Lambi, C. M. (2010). The Limbe Geomorphological High Risk Problematic Environment: An Alternative Land use Paradigm. African Journal of Social Sciences, 1(2), 66-67.

Lambi, C. M. (2009). Conflictual Wetland Utilization in the Ngoketunjia Division, the Upper Nun Valley of Cameroon. Conflict Prevention, Management and Resolution (pp. 11-24). Proceedings of the Postgraduate Seminar organized by the Faculty of Social and Management Sciences of the University of Buea, Cameroon. II PGS Buea, 28th of January 2009.

Lambi, C. M., \& Ndenecho, E. N. (2010). Climographic Analysis and Mapping of the Mount Cameroon Region. Ecology and Natural Resource Development in the Western Highlands of Cameroon (pp. 105-123). Langaa and Publishing CIG, Mankon, Bamenda.

Mafany, G. T. (1999). Impact of the Geology and Sea Water Intrusion on Groundwater Quality in Douala (M.Sc. thesis, pp. 37-54, pp. 66-70). University of Buea.

Maltby, E. (2006). Wetland Conservation and Management: Questions for Science and Society in Applying the Ecosystem Approach. Ecological Studie, 191, 93-115. http://dx.doi.org/10.1007/978-3-540-33189-6_5

Map of Cameroon. (1979). Buea-Douala, 1a, 1b, 1d tif, NB 32- IV, 1: 50000. National Cartographic Institute Yaounde.

Map of Cameroon. (1979). Buea-Douala, NB 32-IV, 1: 200000. National Cartographic Centre Yaounde.

Millennium Ecosystem Assessment. (2003). Ecosystems and human well-being: A framework for assessment. Millennium Ecosystem Assessment. Island Press, Washington D.C. Retrieved from http://www.millenniumassessment.org

Minjo, N. C. (1999). Land Use Changes in the Douala Wetlands: The Case of Bonaberi (M.Sc. thesis, pp. 45-93). University of Buea. 
Ndenecho, E. N. (2005). Biological Resource Exploitation in Cameroon. Crisis to Sustainable Management (pp. 21-22, p. 45). Unique Printers, Bamenda.

Ndenecho, E. N. (2007). Economic valuation and Management of Mangroves Forests in Cameroon. International Journal of Sustainable Development and World Ecology, 14(6). http://dx.doi.org/10.1080/13504500709469759

Ngwa, C. N. (2000). An Evaluation of Risk Zones Around Mount Cameroon Based on Studies of Macroseismicity and Volcanic Products (M.Sc. thesis, p. 34). University of Buea.

Nieuwolt, S. (1978). Tropical Climatology. An Introduction to the Climates of the Low Latitudes (pp. 39- 40). John Wiley and Sons, Ltd.

Orock, F. T. (1996). Alternative Land Management. The Case of the North Eastern Slopes of Buea Sub-Division (Dissertation, Vol. 1, p. 19). University of Yaounde.

Orock, F. T. (2006). Analysis of the Degree of Degradation of Springs and Streams from Perched Aquifers on the Eastern and Southern Slopes of Mount Cameroon (M.Sc. thesis, pp. 8-108). University of Buea.

Ramachandra, T. V., \& Rajinikanth. (2000). Economic Valuation of Wetlands. Technical Report 101. Energy and Wetlands Research Group, Center for Ecological Science, Indian Institute for Science, Bangalore. Retrieved from http://wgbis.ces.ernet.in/energy/water/paper/ecodoc 2004

Richardson, C. J. (2006). Wetlands. In Mays (Ed.), Water Resources Handbook (No. 13, pp. 1-8). McGraw-Hill Co. Inc., New York.

Ripken, C. (2009). Resilience and Vulnerability of Wetlands (M.Sc. thesis, pp. 8-14). Institute of Crop Science and Resource Conservation. Department of Plant Nutrition, Faculty of Agriculture, Rheinische Friedrich-Wilhems- University of Bonn, Germany.

Ruark, S. (2007). Pathogen Profile for Pythium myriotylum. Soilborne pathogens. College of Agriculture and Life Science, North Carolina State University. Retrieved from http://www.cals.ncsu.edu/course/pp728/myriotylum/pythium

Twilley, R. R. (2007). Coastal Wetlands and Global Climate Change. Gulf Coast Wetland Sustainability in a Changing Climate. Pew Center on Global Climate Change. Pewclimate.

United Nations Development Programme. (2006). Millennium Development Goals. Retrieved from $\mathrm{http}: / / \mathrm{www} . u n d p . o r g / \mathrm{mdg} / \mathrm{basics}$

World Wetland Day. (2008). A Message from the Secretary General. Maun, Botswana.

\section{Copyrights}

Copyright for this article is retained by the author(s), with first publication rights granted to the journal.

This is an open-access article distributed under the terms and conditions of the Creative Commons Attribution license (http://creativecommons.org/licenses/by/3.0/). 